\title{
Review of Massimiliano Vatiero's The Theory of Transaction in Institutional Economics: A History. New York, NY: Routledge, 2021, 104 pp.
}

\author{
DOUGLAS W. AlLEN \\ Simon Fraser University
}

This is an odd book. At just eighty pages, it is shorter than most modern applied-micro papers; the hardback cover is thicker than the text! However, with around 250 references, ranging across the past century and several schools of thought, the number of ideas per page is quite staggering. The terse, dense writing, combined with translation issues related to articles/number/plurals between Italian and English, make this a very difficult read. Perhaps this is why, after reading it, I am not fully confident that I understand it. It also partially explains my harsh review.

The structure of the book is simple enough. It lays out four 'institutional' notions of a transaction as described by Ronald Coase, John Commons, Robert Lee Hale, and Oliver Williamson. It then describes three "dimensions" (17) of a transaction: legal, competitive, and political. This is followed by a chapter on each dimension and a short concluding chapter calling for a research agenda. My conjecture of the book's purpose is that the author wants to integrate ideas and expressions of some older institutional writers (most notably Commons and Hale, but also Adolf Berle, Wesley Hohfeld, and Thorstein Veblen) with the works of Coase, Oliver Hart, Williamson, and a few other 'new' institutionalists.

That's all well and good, but I had trouble with the details. This stemmed from the common failure in this genre to carefully define terms. Here is a book on 'the transaction', written within the context of 'institutional economics', yet on the first page the words "institution" and "transaction costs" appear with no definition. Nor is one coming. A few pages later "property rights" show up in a sentence about "market transactions" but with no definition and no explanation of the connection (4). And away we go.

This is problematic because the author obviously has a conception of 'transaction' in mind, and it influences the way he is understanding Coase and others. However, because this understanding is implicit, the book reads as being inconsistent. 
Consider the introductory discussion of Coase's "ideas of transaction" where the author asserts that the "scope" of Coase's 1960 paper was to "question the claim that state intervention in the economy is necessary or desirable" (2). However, in section VI of his 1960 paper, Coase states:

An alternative solution is direct Government regulation. Instead of instituting a legal system of rights [...] the government may impose regulations [...]. Thus, the government [...] may, to deal with the problem of smoke nuisance, decree that certain methods of production should or should not be used [...] or may confine certain types of business to certain districts [...]. (Coase 1960, 17; emphasis added)

It could be argued that Coase gave a justification for state intervention in the economy.

The author wants to claim that Coase "identifies three types of transactions: 1. market transactions, 2. transactions within a firm, and 3. transactions within a super-firm" (4). However, Coase literally does not do this. Coase (1960) believed that 'transactions' only took place in a 'market exchange'. Consider the following from Coase:

Within the firm individual bargains between the various cooperating factors of production are eliminated and for a market transaction is substituted an administrative decision. [...] It does not, of course, follow that the administrative costs of organising a transaction through a firm are inevitably less than the costs of the market transactions which are superseded. [...] This solution would be adopted whenever the administrative costs of the firm were less than the costs of the market transactions that it supersedes and the gains which would result from the rearrangement of activities greater than the firm's costs of organising them. (Coase 1960, 16-17; emphasis added)

Coase did not see the firm as a collection of 'transactions', but rather as an organization where production takes place through direction. The 'transaction' is 'superseded' by a firm. As such, Coase (perhaps confusingly) makes a distinction between the 'costs of market transactions' and 'administrative costs of the firm'. Likewise in Coase's mind, 'super-firms' like governments, do not engage in market exchanges and therefore transactions, but rather governments direct production through statute, regulations, and zoning, among other things.

I happen to believe, probably along with the author, that production involves a system of property right exchanges, and that these can be de- 
fined as various forms of a transaction. In this light, Coase could be interpreted as 'identifying three types of transactions'. Had the author developed a definition and theory of 'a transaction' such an interpretation would make sense, but as it stands the text comes across as muddled.

A bigger problem is the book's treatment of the Coase Theorem. Coase wrote the first four sections of the 1960 paper not to describe the real world, not to make some type of normative policy suggestion, but to criticize the neoclassical model of economics. The Coase Theorem simply states: if transaction costs are zero, then the allocation of resources is independent of the distribution of economic property rights (Allen 2000). Since the neoclassical model (whether in its perfectly competitive form or any other version) implicitly assumes zero transaction costs, then it cannot have anything to say about the distribution of economic property rights. In other words, it cannot be used for understanding organizations and institutions. As Coase stated at the end of section VI: "the problem is one of choosing the appropriate social arrangement for dealing with the harmful effects" $(1960,18)$.

Consider this claim by the author: "the difference between the Coase theorem world and the perfect competition framework is represented by this legal dimension, consisting of the active role of the public official actor in defining and enforcing rights" (20-21). Rights in "the Coase theorem world' just exist without cost. They are not defined or enforced by anyone. If such a public official existed, he would be in a real world, not the imaginary world of zero transaction costs. For this reason, it is also not a "corollary to the Coase theorem [...] that the law [...] should be designed by a public official actor to lower transaction costs" (21). If we were in a 'Coase theorem world', transaction costs would be zero, and could not be lower.

This sort of troubling logical inconsistency is all over the place when it comes to Coase, but I will point out one particular instance of importance. Chapter 3 is devoted to the "legal dimension of transactions" (33), and a great deal of time is spent on the concept of 'positional' goods-goods where relative consumption matters along with the level of consumption. The climax of the chapter comes with the declaration that specific laws are positional. Therefore, the allocation of property rights is positional, and as a result there are not just concerns over social costs, but also of positional status. Each allocation of rights "creates or redistributes legal positions that are characterized by positional concerns" (45). This means that "no (property) right is a 'free lunch' [... and therefore 
rights are] never neutral, as the Coase theorem instead suggests" (46). This conclusion does not follow, and results from having a positive transaction cost slip into the analysis: namely the 'political actor' is switching rights around without a compensation (that is, a theft), and this cannot happen under zero transaction costs. Allen (2015) discusses this in the more famous case of the Coase Theorem holding only if income is held constant.

I found it odd that there was so much emphasis on Hart and Williamson in the book. Chapter 4 on the "competitive dimension of transactions" (49) is entirely devoted to the different treatments by Hart and Williamson on specific investments and the problem of hold-up. The problem of holdup is at best a special case of a transaction cost problem, and Hart and Williamson (though important players) are hardly all there is when it comes to incomplete contracts and asymmetric information. Conspicuous in their absence from the book are Armen Alchian, Yoram Barzel, and Stephen Cheung - the very ABC's of property rights.

Which leads to the book's big claim, found in the final two-page chapter, which states that the book leads to a 'remarkable research proposal'. What is this proposal? That "future works should study these transaction costs theoretically and empirically" (79). For someone who first defined transaction costs in $1988^{1}$ and who has worked (along with hundreds of others) on the theoretical and empirical content of transaction cost economics ever since, this research proposal came as a surprise. What have all the institutional economists been up to for the past 30 years?

The book is not without some merit. Many of the ideas of the old institutionalists and legal realists were solid, and there is often a strong correspondence with modern institutional ideas. For example, Hale's work on legal rights can be linked quite readily to the works of Alchian, Barzel, and others. For those unfamiliar with the work of Commons, this book provides a very brief introduction. Unfortunately, it doesn't go much beyond this.

\section{REFERENCES}

Allen, Douglas W. 1988. “A Transaction Cost Theory of Marriage and Divorce.” PhD Dissertation, University of Washington.

Allen, Douglas W. 1991. "What are Transaction Costs?" Research in Law and Economics 14: 1-18.

\footnotetext{
${ }^{1}$ See Allen (1988, chapter 2; also, cf. 1991).
} 
Allen, Douglas W. 2000. "Transaction Costs.” In Encyclopedia of Law and Economics. Volume I: The History and Methodology of Law and Economics, edited by Boudewijn Bouckaert, and Gerrit De Geest, 893-926. Cheltenham: Edward Elgar Publishing.

Allen, Douglas W. 2015. "The Coase Theorem: Coherent, Logical, and not Disproved." Journal of Institutional Economics 11 (2): 379-390.

Coase, Ronald H. 1960. "The Problem of Social Cost." The Journal of Law \& Economics 3: $1-44$.

Douglas W. Allen is the Burnaby Mountain Professor of Economics at Simon Fraser University, Burnaby, British Columbia. He is the author of The Institutional Revolution: Measurement and the Economic Emergence of the Modern World.

Contact e-mail: <doug_allen@sfu.ca> 